\title{
INCREASING THE NUTRITIONAL VALUE OF BISCUITS BY ADDING LOW COST NEUTRAL SOURCES OF HIGH PROTEIN AND MINERALS
}

(Received:6.4.2014)

\author{
By \\ M.A.Asael, M.H Abd El-Kader and O. S. Ragab \\ Bread and Pastries Research Department, Food Technology Research institute, \\ Agriculture Research Center, Egypt
}

\begin{abstract}
The present study was conducted to prepare low cost dry meal, high in nutrient requirements of protein and minerals, as well as long shelf life for school children. Biscuits were supplemented with high protein sources as inactive dry yeast to overcome protein deficiency problem, with adding cinnamon for mineral supply, especially iron, zinc, calcium and manganese. Inactive dry yeast was added to wheat flour in rich biscuits at four replacement levels $(5,10,15$ and 20\%). The cinnamon was added to all biscuits (3\%). Chemical composition of inactive dry yeast and cinnamon as well as biscuits were determined. The physical properties and sensory evaluation of biscuits were investigated. Mineral analysis and vitamin B complex were determined in biscuits. The biscuits supplemented with inactive dry yeast were recorded acceptable for all percentages, whereas the percentage $10 \%$ recorded the highest score in overall acceptability.
\end{abstract}

Key words :biscuits, cinnamon, inactive dry yeast, protein.

\section{INTRODUCTION}

Egyptian children suffer severe malnutrition problems, due to protein and minerals deficiency. These problems affect the growth and understanding of school children.

Malnutrition affects people of every age, although infants, children, and adolescents may suffer the most because many nutrients are critical for normal growth and development. Malnutrition is insufficient, excessive or imbalanced consumption of protein, energy or micronutrients (vitamins and minerals). There are two types of malnutrition; protein-energy malnutrition (PEM), arises due to inadequate intake of calories from proteins, such as fish and meat, and vitamins and minerals, such as zinc, iron and vitamin A. The second type is micromalnutrition, refers to mineral and vitamin deficiency. Both conditions can have serious negative consequences for physical and mental health (LINDS, 2007). Malnutrition not only harms the body but leaves an imprint on the minds of those who survive it. Research has revealed that poor diet during early development (0-3yrs of age) leads to learning and memory deficts, lower of age IQ and school achievements, and behavioral problems in childhood and adolescence (Lui et al., 2004).

Approximately $25 \%$ of the Egyptian children under age five have chronic malnutrition, with rural children slightly more likely to be stunted than their urban counterparts $(26 \%$ and $23 \%$, respectively). The highest proportion of underweight and the high level of stunting seen in Upper Egypt appear to be due to insufficient household food security, inadequate feeding and caring practices, and high infection rates. Malnutrition disorders affect more than $30 \%$ of school children in Egypt. Iron deficiency, anemia, is by far the most common nutritional disorder. But, subclinical vitamin A deficiencies and other micronutrient deficiencies are also present. Children who are stunted, anemic have poorer school performance including poor attendance, behavior, cognition and achievement levels ( Ibrahim, 2004).

Dry yeast, a by-product of ethanol industries, is composed of inactive cells of Saccharomyces cerevisiae, which is a rich source of protein, vitamins (mainly B complex) and minerals such as iron, zinc and selenium. It also has a carbohydrate fraction (20\% to $40 \%$ ) consisting mostly of cell wall and a significant amount of nucleotides (Araújo and Silva, 2009). 
Food grade yeasts are used as sources of high nutritional value proteins, enzymes and vitamins, with applications in the health food industry as nutritional supplements, as food additives, conditioners and flavouring agents, for the production of microbiology media, as well as livestock feeds (Bekatorou et al., 2006).

The limit for utilizing yeast protein in human consumption is due to its relatively high amount of nuclic acids level (purine and pyrimidine) which results in increasing the levels of uric acid in blood .The safe intake of yeast protein is about 20-30 gm /day ( Hedenskog and Mogran, 1973).

There are different methods that have been discribed for reducing nuclic acids content of yeast. The methods including heat and chemical treatments (Eid,1977 and Asad, 1983).

Dobrzanski et al.(2003) mentioned that chemical constitutes of dry yeasts (Saccharomyces cerevisiae) enriched with chromium, selenium and zinc ranged between 4.67 to 6.13 for ash; 35.89 to 40.51 for protein content and 0.94 to 1.21 for fat, respectively, while the crude fiber was traces. Pozo-Bayón et al. (2009) reported that, commercial inactive yeast preparations are obtained from Saccharomyces cerevisiae after thermal inactivation once they have grown in aerobic conditions on highly concentrated sugar media. They can be classified in four types depending on the manufacture process employed for their production:

(1) inactive yeast (obtained by thermal inactivation followed by drying). (2) yeast autolysates (in addition to thermal inactivation there is an incubation step allowing the enzymes to be released from the vacuoles, thus degrading part of the intracellular cell content). (3) yeast hulls or walls (the insoluble component formed by yeast walls without cytoplasmic content). (4) yeast extracts (the soluble extract after the total degradation of the cytoplasmic content).

During thermal drying, yeast may undergo numerous changes such as destruction of cell membranes, denaturation of proteins or enzymes, or even death (Adamiec et al., 1995).

Cinnamon's unique healing abilities come from three basic types of components in the essential oils found in its bark. These oils contain active components called cinnamaldehyde, cinnamyl acetate, and cinnamyl alcohol, plus a wide range of other volatile substances. Cinnamon contains a high amount of carbohydrate and low amount of ash plus a high amount of potassium and important compounds like Cinnamaldehyde, eugenol, cinnamic acid and cinnamate. It has good anti-inflammatory, anti-oxidant, anti-ulcer, anti-microbial, antidiabetic, memory enhancer and many other activities. Cinnamon is an excellent source of fiber and very good source of calcium while it contains traces of manganese. The combination of calcium and fiber in cinnamon is important and can be helpful for the prevention of several different conditions. Both calcium and fiber can bind to bile salts and lead to remove them from the body. By removing bile, fiber helps to prevent the damage that certain bile salts can cause to colon cells, thereby reducing the risk of colon cancer. In addition, when bile is removed by fiber, the body must break down cholesterol in order to make new bile. This process can help to lower high cholesterol levels, which can be helpful in preventing atherosclerosis and heart disease. For sufferers of irritable bowel syndrome, the fiber in cinnamon may also provide relief from constipation or diarrhea (Anown, 2013).

The present study aimed to prepare low cost dry biscuits rich in protein and minerals for school children to cover the daily requirements of nutrient.

\section{MATERIALS AND METHODS}

\subsection{Materials}

2.1.1. Soft wheat flour ( $72 \%$ extraction) was obtained from five stars milling, Odabia Suez, Egypt.

2.1.2. Inactive dry yeast was obtained from Egyptian Starch, yeast \& detergents company, Cairo, Egypt.

2.1.3.Cinnamon, skim milk, butter, sugar, baking powder were obtained from the local market. Giza, Egypt.

2.1.4. Sweet whey milk liquid was obtained from El Amireya, Cairo, Egypt from Misr for Dairy and Food Company.

2.1.5. Chemicals used in this study were purchased from El-Gomhoria Company, Egypt.

\subsection{Methods}

\subsubsection{Preparation of biscuits}

Biscuit formula as shown in Table (1) according to Saba (2005) was used for biscuits preparing as shown in the following steps:

1- Sugar mixed with butter to creamy foam.

2- Inactive dry yeast dissolved in liquid sweet whey milk. 
3-The dry ingredients in biscuit formula (cinnamon, skim milk powder and baking powder) were mixed with flour.

\subsubsection{Organoleptic characteristics of biscuits}

Organoleptic characteristics of the biscuits were evaluated by ten panelists for various

Table (1): The formula of biscuits supplemented with inactive dry yeast and cinnamon.

\begin{tabular}{|l|c|c|c|c|c|c|c|c|}
\hline Ingredient & $\begin{array}{c}\text { Flour } \\
(\mathbf{g})\end{array}$ & $\begin{array}{c}\text { Inactive } \\
\text { dry } \\
\text { yeast(g) }\end{array}$ & $\begin{array}{c}\text { Cinnamon } \\
(\mathbf{g})\end{array}$ & $\begin{array}{c}\text { Skim } \\
\text { milk } \\
\text { powder } \\
\text { Treatment }\end{array}$ & $\begin{array}{c}\text { Sweet } \\
\text { whey } \\
\text { milk } \\
(\mathbf{m l})\end{array}$ & $\begin{array}{c}\text { Fat } \\
(\mathbf{g})\end{array}$ & $\begin{array}{c}\text { Sugar } \\
(\mathbf{g})\end{array}$ & $\begin{array}{c}\text { Baking } \\
\text { powder } \\
(\mathbf{g})\end{array}$ \\
\hline control & $\mathbf{1 0 0}$ & - & - & - & - & 20 & 28 & 1.5 \\
\hline $\mathbf{5 \%}$ & $\mathbf{9 5}$ & $\mathbf{5}$ & $\mathbf{3}$ & $\mathbf{6}$ & $\mathbf{4}$ & $\mathbf{2 0}$ & $\mathbf{2 8}$ & $\mathbf{1 . 5}$ \\
\hline $\mathbf{1 0 \%}$ & $\mathbf{9 0}$ & $\mathbf{1 0}$ & $\mathbf{3}$ & $\mathbf{6}$ & $\mathbf{4}$ & $\mathbf{2 0}$ & $\mathbf{2 8}$ & $\mathbf{1 . 5}$ \\
\hline $\mathbf{1 5 \%}$ & $\mathbf{8 5}$ & $\mathbf{1 5}$ & $\mathbf{3}$ & $\mathbf{6}$ & $\mathbf{4}$ & $\mathbf{2 0}$ & $\mathbf{2 8}$ & 1.5 \\
\hline $\mathbf{2 0 \%}$ & $\mathbf{8 0}$ & $\mathbf{2 0}$ & $\mathbf{3}$ & $\mathbf{6}$ & $\mathbf{4}$ & $\mathbf{2 0}$ & $\mathbf{2 8}$ & $\mathbf{1 . 5}$ \\
\hline
\end{tabular}

The formula in step (No. 3) was added to the mixture in step (No. 1) and finally the blends in step (No. 2) to obtain dough. The dough was formulated in a thin sheet and cut to circular shape $1 / 2 \mathrm{~cm}$ in the thickness. Afterwards, the biscuits were baked in the oven at $160^{\circ} \mathrm{C}$ for 18 $20 \mathrm{~min}$. to reach a golden color.

\subsubsection{Analytical methods}

Samples were analyzed for moisture, crude fiber, fat, ash and crude protein content as described in the A.O.A.C. (2005). While, total carbohydrates in the dry samples were calculated by difference (total carbohydrate $\%=100$ [fat $\%+$ crude protein $\%+$ fiber $\%+$ ash \%]). Total dietary fibers were determined according to Prosky et al. (1984). Energy value was calculated according to James (1995) using the following equation:

Energy value (in kcal per $100 \mathrm{~g}$ dry weight $)=$ $4 x(\%$ protein $)+9 x(\%$ fat $)+4 x(\%$ carbohydrate).

\subsubsection{Determination of minerals}

Minerals were determined according to the method described by A.O.A.C. (2005) using the dry ashing method for the preparation of samples. The Perkin Elmer Model 4100Z1 (USA) Atomic Absorption spectrophotometer was used for the determination of minerals.

\subsubsection{Determination of $B$ complex vitamins}

B complex vitamins were determined using HPLC according to the method described by Batifoulier et al.(2005).

\subsubsection{Determination of dietary references intakes (\% DRIs)}

Dietary reference intakes (\% DRIs) which estimate the average requirements for prepared biscuits were calculated according to Food and Nutrition Board (2011).

$\% R D A=\frac{\text { Value of nutrient in sample of biscuits }}{\text { RDA for the same nutrient }} X 100$ quality attributes such as appearance, taste, texture, color and odor .

\subsubsection{Physical properties of biscuits}

The physical characters of biscuits ( diameter, thickness, moisture, expansion, volume, weight and $\mathrm{V} / \mathrm{W}$ ratio) were determined according to A.A.C.C (2002).

\subsubsection{Statistical analysis}

Data were statistically analyzed by the variance and least significant difference (L.S.D) at 0.05 level according to the method described by McClave and Benson (1991).

\section{RESULTS AND DISCUSSION}

3.1. Chemical composition of wheat flour $(72 \%$ ext.), inactive dry yeast, cinnamon powder, skim milk and sweet whey powder

Data given in Table (2) showed that the inactive dry yeast had the highest content of ash and protein followed by skim milk powder. The results agree with Abou-Zaid (1984) who mentioned that the chemical composition of inactive dry yeast was $13.79,0.62,39.0,3.13$ and $43.46 \%$ in ash lipids, protein, fiber and carbohydrates content. El-Bastawesy et al. (2013) reported that the protein, ash and fat content of skim milk were $31.89,7.93,0.92 \%$, respectively. The fiber content as well as the fat content were higher in cinnamon compared with the other ingredient. The cinnamon analysis was close to the data reported by Gul and Safdar (2009). They reported that the protein, fat, ash and fiber contents of cinnamon were 3.5, 4.0, 2.4 and $33.0 \%$, respectively. The results of wheat flour $72 \%$ extraction were in agreement with Ali,Zeinab et al. (2013). They found that protein, fat, fiber and ash were 10.52, 0.77, 0.87 and $0.60 \%$, respectively. 
Table (2): The chemical composition of raw materials (on a dry weigh basis).

\begin{tabular}{|l|c|c|c|c|c|}
\hline \multicolumn{1}{|c|}{ Ingredient } & $\begin{array}{c}\text { Protein } \\
\%\end{array}$ & $\begin{array}{c}\text { Fat } \\
\%\end{array}$ & $\begin{array}{c}\text { Ash } \\
\%\end{array}$ & $\begin{array}{c}\text { Crude Fiber } \\
\%\end{array}$ & $\begin{array}{c}\text { T.C } \\
\%\end{array}$ \\
\hline Wheat flour 72\% & 10.22 & 0.9 & 0.44 & 0.42 & 88.02 \\
\hline Inactive dry yeast & 51.60 & 1.14 & 11.20 & 6.61 & 29.45 \\
\hline Cinnamon & 3.62 & 3.65 & 2.51 & 29.33 & 60.89 \\
\hline Skim milk powder & 35.22 & $\mathbf{0 . 7 4}$ & $\mathbf{8 . 3 2}$ & - & 55.72 \\
\hline Sweet whey liquid & 4.9 & $\mathbf{0 . 8}$ & $\mathbf{0 . 6}$ & - & 93.7 \\
\hline
\end{tabular}

T.C (Total carbohydrates) .

\subsection{Chemical composition of the produced biscuits}

Data in Table (3) showed the chemical composition of the biscuits supplemented with inactive dry yeast. The results showed gradual increase in protein, fat, ash and fiber contents by increment of inactive dry yeast level in biscuits. The protein content varied between $6.64 \%$ to 14.62 for the control biscuits and the biscuits supplemented with $20 \%$ inactive dry yeast.

The increment of protein percentage reached $120 \%$ in the high level of supplementation. The same trend was found with ash content which increased by $69 \%$ in the biscuits supplemented with $20 \%$ inactive dry yeast compared with the control. The fiber content ranged between 0.77 $\%$ in the control and $1.78 \%$ in the high level of supplementation. The biscuits supplemented by inactive dry yeast and cinnamon showed
Zinc (Zn)] for the biscuit supplemented with inactive dry yeast at 5\%,10\%, 15\% and 20\% levels and the control. The minerals content of biscuits gradually increased in $\mathrm{K}, \mathrm{Mg}, \mathrm{Fe}$ and $\mathrm{Zn}$ as the supplementation with inactive dry yeast increased. Meanwhile, the calcium decreased by increasing the level of supplementation. The increase percentages varied in minerals between samples and its control which were $42 \%$ in $\mathrm{K}, 25 \%$ in $\mathrm{Mg}, 7 \%$ in $\mathrm{Mn}, 94 \%$ in $\mathrm{Fe}, 54 \%$ in $\mathrm{Zn}$ and reached $400 \%$ in $\mathrm{Ca}^{++}$although the percentage of $\mathrm{Ca}^{++}$ decreased by increasing the level of supplementation. These results may be due to the high minerals content of inactive dry yeast. The results are in agreement with (Eid 1977) who mentioned that mineral contents of heat shock bakers yeast were $\mathrm{Ca} 139, \mathrm{~K} 1522, \mathrm{Mn}$ $120 \mathrm{mg} / 100 \mathrm{gm}$ and $\mathrm{Zn} 50 \mu \mathrm{g} / 100 \mathrm{gm}$.

Table (3): The chemical composition of the biscuits supplemented with different levels of inactive dry yeast (on a dry weigh basis).

\begin{tabular}{|c|c|c|c|c|c|c|c|}
\hline $\begin{array}{c}\text { Biscuit } \\
\text { Samples }\end{array}$ & $\begin{array}{c}\text { Protein } \\
\%\end{array}$ & $\begin{array}{c}\text { Fat } \\
\%\end{array}$ & $\begin{array}{c}\text { Ash } \\
\%\end{array}$ & $\begin{array}{c}\text { Crude } \\
\text { Fiber } \\
\%\end{array}$ & $\begin{array}{c}\text { T.C } \\
\%\end{array}$ & $\begin{array}{c}\text { TDF } \\
\%\end{array}$ & $\begin{array}{c}\text { Total Calorie } \\
\text { (kcal) }\end{array}$ \\
\hline Control & 6.64 & 14.10 & 1.37 & 0.32 & 77.57 & 2.46 & 463.74 \\
\hline $5 \%$ & 10.51 & 14.05 & 1.98 & 1.68 & 71.78 & 2.98 & 455.61 \\
\hline $10 \%$ & 11.80 & 14.08 & 1.50 & 1.88 & 70.74 & 3.49 & 456.88 \\
\hline $15 \%$ & 13.10 & 14.10 & 2.22 & 2.26 & 68.32 & 4.02 & 452.58 \\
\hline $20 \%$ & 14.62 & 14.13 & 2.32 & 2.77 & 66.16 & 4.53 & 446.29 \\
\hline
\end{tabular}

increased total dietary fiber in samples compared with the control. Meanwhile, the total calories decreased.

3.3. The mineral content of biscuits supplemented with different levels of inactive dry yeast.

Table (4) showed the composition of elements [Potassium (K). Magnesium ( $\mathrm{Mg}$ ), Manganese $(\mathrm{Mn})$, iron $(\mathrm{Fe})$, Calcium $(\mathrm{Ca})$ and
3.4. The B vitamin content of biscuits supplemented with different levels of inactive dry yeast.

The data in Table (5) showed the content of B complex vitamins in biscuits supplemented with $5,10,15$ and $20 \%$ inactive dry yeast. The data showed an increase in all vitamin B complex ( Thiamine, Riboflavin, Nicotinic, B6, Folic and B12). The high increase was found in 
Table (4): The mineral content of biscuits supplemented with different levels of inactive dry yeast (mg/100g biscuits).

\begin{tabular}{|l|c|c|c|c|c|c|}
\hline $\begin{array}{l}\text { Biscuit } \\
\text { samples }\end{array}$ & $\begin{array}{c}\text { K } \\
\mathbf{m g}\end{array}$ & $\begin{array}{c}\text { Mg } \\
\mathbf{m g}\end{array}$ & $\begin{array}{c}\text { Mn } \\
\mathbf{m g}\end{array}$ & $\begin{array}{c}\text { Fe } \\
\text { mg }\end{array}$ & $\begin{array}{c}\text { Ca } \\
\text { mg }\end{array}$ & $\begin{array}{c}\text { Zn } \\
\text { mg }\end{array}$ \\
\hline Control & $\mathbf{1 3 1 . 8 2}$ & $\mathbf{3 3 . 8 9}$ & $\mathbf{1 1 . 7 9}$ & $\mathbf{1 . 6 3}$ & $\mathbf{2 2 . 1 2}$ & $\mathbf{0 . 7 0}$ \\
\hline $\mathbf{5 \%}$ & $\mathbf{1 4 9 . 3 5}$ & $\mathbf{3 6 . 0 6}$ & $\mathbf{1 2 . 5 9}$ & $\mathbf{1 . 9 9}$ & $\mathbf{1 2 8 . 4 5}$ & $\mathbf{0 . 8 6}$ \\
\hline $\mathbf{1 0 \%}$ & 156.07 & $\mathbf{3 8 . 2 1}$ & $\mathbf{1 2 . 6 0}$ & $\mathbf{2 . 3 0}$ & $\mathbf{1 2 5 . 1 2}$ & $\mathbf{0 . 9 5}$ \\
\hline $\mathbf{1 5 \%}$ & 171.93 & $\mathbf{4 0 . 3 8}$ & $\mathbf{1 2 . 2 5}$ & $\mathbf{2 . 7 4}$ & $\mathbf{1 2 1 . 9 5}$ & $\mathbf{0 . 9 7}$ \\
\hline $20 \%$ & $\mathbf{1 8 8 . 1 2}$ & $\mathbf{4 2 . 5 3}$ & $\mathbf{1 2 . 6 7}$ & $\mathbf{3 . 1 7}$ & $\mathbf{1 1 8 . 4 7}$ & $\mathbf{1 . 0 8}$ \\
\hline
\end{tabular}

Table (5): The B vitamin content of biscuits supplemented with different levels of inactive dry yeast ( $\mathrm{mg} / \mathbf{1 0 0 g}$ biscuits).

\begin{tabular}{|l|c|c|c|c|c|c|}
\hline $\begin{array}{c}\text { Biscuit } \\
\text { samples }\end{array}$ & $\begin{array}{c}\text { Thiamin } \\
\mathrm{mg}\end{array}$ & $\begin{array}{c}\text { Riboflavin } \\
\mathrm{mg}\end{array}$ & $\begin{array}{c}\text { Nicotinic } \\
\mu \mathrm{g}\end{array}$ & $\begin{array}{c}\mathrm{B6} \\
\mathrm{mg}\end{array}$ & $\begin{array}{c}\text { Folic } \\
\boldsymbol{\mu g}\end{array}$ & $\begin{array}{c}\text { B12 } \\
\mathrm{mg}\end{array}$ \\
\hline Control & 1.00 & 2.00 & 10.00 & 0.30 & 1.20 & 0.50 \\
\hline $5 \%$ & 2.62 & 4.41 & 16.50 & 2.01 & 9.91 & 2.11 \\
\hline $10 \%$ & 3.27 & 4.71 & 18.62 & 2.91 & 11.12 & 3.52 \\
\hline $15 \%$ & 4.00 & 4.95 & 20.85 & 3.68 & 13.35 & 4.91 \\
\hline $20 \%$ & 4.83 & 5.21 & 23.21 & 4.12 & 15.81 & 6.12 \\
\hline
\end{tabular}

B6 followed by Folic acid and B $12(1273,1218$ and $1124 \%$, respectively). On the other hand, the lower increase was found in Nicotinic, Riboflavin, Thiamine (132, 160 and 383\%, respectively). Bekatorou et al. (2006) mentioned that yeasts are used as alternative sources of high nutritional value proteins, enzymes and vitamins.

3.5. Sensory evaluation of biscuits supplemented with inactive dry yeast

The organoleptic evaluation of biscuits prepared with different levels of inactive dry yeast supplementation is present in Table (6). The results of sensory evaluation of biscuits supplemented with 5, 10, 15 and $20 \%$ of inactive dry yeast, showed no significant differences between different levels of supplementation with inactive dry yeast in appearance, color and odor, but a little significant difference among samples and the control. A minor significant different was observed in texture and taste in samples supplemented with inactive dry yeast compared with the control. All different levels of inactive

Table (6): Sensory evaluation of biscuits supplemented with inactive dry yeast.

\begin{tabular}{|c|c|c|c|c|c|c|c|}
\hline $\begin{array}{c}\text { Biscuit } \\
\text { samples }\end{array}$ & $\begin{array}{c}\text { Appearance } \\
\text { (20) }\end{array}$ & $\begin{array}{c}\text { color } \\
(20)\end{array}$ & $\begin{array}{l}\text { Texture } \\
\text { (20) }\end{array}$ & $\begin{array}{l}\text { Taste } \\
(20)\end{array}$ & $\begin{array}{l}\text { Odor } \\
(\mathbf{2 0})\end{array}$ & $\begin{array}{l}\text { Total } \\
\text { score } \\
(100)\end{array}$ & Acceptance \\
\hline Control & $14.9^{b}$ & $15.7^{\mathrm{b}}$ & $18.65^{\mathrm{a}}$ & $18.5^{\mathrm{a}}$ & $15.7^{\mathrm{b}}$ & $83.45^{b}$ & $\mathbf{G}$ \\
\hline $5 \%$ & $16.4^{\mathrm{a}}$ & $17.1^{\mathrm{a}}$ & $17.15^{\mathrm{a}}$ & $16.2^{b}$ & $17.55^{\mathrm{a}}$ & $84.40^{b}$ & $\mathbf{G}$ \\
\hline $10 \%$ & $17.0^{\mathrm{a}}$ & $18.1^{\mathrm{a}}$ & $17.05^{b}$ & $15.5^{\mathrm{b}}$ & $17.45^{\mathrm{a}}$ & $85.10^{\mathrm{a}}$ & $\mathbf{G}$ \\
\hline $15 \%$ & $17.15^{\mathrm{a}}$ & $17.75^{\mathrm{a}}$ & $16.3^{b}$ & $15.1^{\mathrm{b}}$ & $17.05^{\mathrm{a}}$ & $83.35^{b}$ & $\mathbf{G}$ \\
\hline $20 \%$ & $17.2^{\mathrm{a}}$ & $17.8^{\mathrm{a}}$ & $16.0^{b}$ & $15.0^{b}$ & $16.21^{\mathrm{ab}}$ & $82.21^{b}$ & $\mathbf{G}$ \\
\hline L.S.D & 2.14 & 1.84 & 1.56 & 1.75 & 1.95 & 1.54 & \\
\hline
\end{tabular}

$(\mathrm{P}<0.05)$ a, b, ab, c and d. 100-90 Very good (V), 89-80 Good(G),79-70 Satisfactory (S). 
dry yeast supplementation showed good acceptance in sensory evaluation, otherwise, the level of 10\% supplementation recorded the highest score (85.1). The obtained data of sensory evaluation showed acceptability for biscuits supplemented with 5,10,15 and $20 \%$ of inactive dry yeast without significant difference.

\subsection{Physical characteristics of biscuits supplemented with inactive dry yeast.}

The physical properties of the prepared biscuits, i.e., diameters, thickness, expansion factor, volume, weight and specific volume are shown in Table (7). The results indicated that diameter was increased reversely with thickness. The expansion factor increased gradually from 10.02 to $11.27 \mathrm{~mm}$ for $5 \%$ and $20 \%$,respectively of the supplemented biscuits. The specific volume values in the supplemented biscuits were lower than the control. The decrease in specific volume of biscuit samples could be attributed to the increasing of inactive dry yeast supplementation in biscuits.
3.7. The dietary references intake from biscuits supplemented with inactive dry yeast.

The dietary references intake of (RDI) for protein, thiamin, riboflavin, $\mathrm{B} 6, \mathrm{Fe}, \mathrm{Zn}$, and $\mathrm{Mg}$ are presented in Table (8). It can be seen that $100 \mathrm{~g}$ of biscuits supplemented with $20 \%$ inactive dry yeast cover $43.0 \%$ of the daily total protein and the dietary references intake for $\mathrm{Fe}$, $\mathrm{Zn}$ and $\mathrm{Mg}$ cover 53.73, 15.44 and 21.27\% respectively of daily requirement. In the case of B vitamins (thiamin, riboflavin, B6), it cover more than the daily requirement.

From the results of this work it could be concluded that inactive dry yeast and cinnamon could be used to produce rich protein, vitamin and mineral biscuits. The supplementation could reach up to $20 \%$ without significant differences in the acceptability. The intake of $100 \mathrm{~g}$ biscuits supplemented with inactive dry yeast and cinnamon cover the requirement of thiamin, riboflavin, B6 and moderate amount of protein, $\mathrm{Fe}, \mathrm{Zn}$, and $\mathrm{Mg}$.

Table (7): Physical characteristics of biscuits supplemented with different levels of inactive dry yeast.

\begin{tabular}{|l|c|c|c|c|c|c|}
\hline $\begin{array}{l}\text { Biscuit } \\
\text { samples }\end{array}$ & $\begin{array}{c}\text { Diameter } \\
(\mathbf{D})(\mathbf{m m})\end{array}$ & $\begin{array}{c}\text { Thickness } \\
(\mathbf{T})(\mathbf{m m})\end{array}$ & $\begin{array}{c}\text { Expansion } \\
\text { factor }(\mathbf{D} / \mathbf{T})\end{array}$ & $\begin{array}{c}\text { Volume } \\
\left(\mathbf{C m}^{3}\right)\end{array}$ & $\begin{array}{c}\text { Weight } \\
(\mathbf{g m})\end{array}$ & $\begin{array}{c}\text { V/W ratio } \\
\left(\mathbf{C m}^{3} / \mathbf{g m}\right)\end{array}$ \\
\hline Control & 43.8 & 5.28 & 8.29 & 10.9 & 7.93 & 1.50 \\
\hline $5 \%$ & 44.2 & 4.41 & 10.02 & 11.10 & 8.10 & 1.37 \\
\hline $10 \%$ & 44.8 & 4.25 & 10.54 & 11.21 & 8.41 & 1.33 \\
\hline $15 \%$ & 45.0 & 4.10 & 10.97 & 11.32 & 8.32 & 1.36 \\
\hline $20 \%$ & 45.1 & 4.00 & 11.27 & 11.41 & 8.50 & 1.34 \\
\hline
\end{tabular}

Table (8): The percentage of dietary reference intake of (RDI) for some nutrients in $100 \mathrm{~g}$ biscuits supplemented with inactive dry yeast for children (5-13 years).

\begin{tabular}{|c|c|c|c|c|c|c|c|}
\hline Biscuit samples & Protein & Thiamin & $\begin{array}{c}\text { Riboflavi } \\
\text { n }\end{array}$ & B6 & Fe & Zn & Mg \\
\hline Recomended /daily & $\mathbf{3 4 g}$ & $\mathbf{0 . 7 m g}$ & $\mathbf{0 . 8 m g}$ & $\mathbf{0 . 8 m g}$ & $\mathbf{5 . 9 m g}$ & $\mathbf{7 . 0 m g}$ & $\mathbf{2 0 0 m g}$ \\
\hline Control & $\mathbf{1 9 . 5 3}$ & $\mathbf{1 4 2 . 8 6}$ & $\mathbf{2 5 0 . 0 0}$ & $\mathbf{3 7 . 5}$ & $\mathbf{2 7 . 6 3}$ & $\mathbf{1 0 . 0 2}$ & $\mathbf{1 6 . 9 5}$ \\
\hline $\mathbf{5 \%}$ & $\mathbf{3 0 . 9 1}$ & $\mathbf{3 7 4 . 5 7}$ & $\mathbf{4 4 1 . 2 0}$ & $\mathbf{2 5 1 . 2 5}$ & $\mathbf{3 3 . 7 3}$ & $\mathbf{1 2 . 3 4}$ & $\mathbf{1 8 . 0 3}$ \\
\hline $10 \%$ & $\mathbf{3 4 . 7 1}$ & $\mathbf{4 6 6 . 8 6}$ & $\mathbf{5 8 8 . 8 8}$ & $\mathbf{3 6 3 . 7 5}$ & $\mathbf{3 8 . 9 8}$ & $\mathbf{1 3 . 5 7}$ & $\mathbf{1 9 . 1 1}$ \\
\hline $15 \%$ & $\mathbf{3 8 . 5 3}$ & $\mathbf{5 7 1 . 5 7}$ & $\mathbf{6 1 8 . 8 8}$ & $\mathbf{4 6 0 . 0 0}$ & $\mathbf{4 6 . 4 4}$ & $\mathbf{1 3 . 7 8}$ & $\mathbf{2 0 . 1 9}$ \\
\hline $20 \%$ & $\mathbf{4 3 . 0 0}$ & $\mathbf{6 9 0 . 1 4}$ & $\mathbf{6 5 1 . 5 0}$ & $\mathbf{5 1 5 . 0 0}$ & $\mathbf{5 3 . 7 3}$ & $\mathbf{1 5 . 4 4}$ & $\mathbf{2 1 . 2 7}$ \\
\hline
\end{tabular}




\subsection{Total cost of biscuits supplemented with different levels of inactive dry yeast.}

The total cost of biscuits (Table 9) showed a slightly increase in cost of $100 \mathrm{~g}$ of biscuits supplemented with inactive dry yeast than the control one. The cost increased by about $28 \%$ in highly supplemented biscuits with inactive dry yeast compared with the control. These increases are considerably small for the advantages of supplementation.
A.O. A. C. (2005). Official Methods of Analysis of the Association of Official Analytical Chemists. Arlington, Virginia, USA.

Araújo F.F. and Silva C.C. (2009). Leveduras hidrolisadas e inativas. In: Congresso International Sobre O Uso De Levedura NA Alimentacao Animal , 1., 2009, Campinas. Anais. Campinas: Colégio Brasileiro de Nutrição Animal, 2009. p.37-44.

Table (9): The approximately total cost of biscuits supplemented with different levels of inactive dry yeast.

\begin{tabular}{|l|c|c|c|c|c|c|c|c|c|c|}
\hline \multirow{2}{*}{ Ingredients } & \multicolumn{2}{|c|}{ Control } & \multicolumn{2}{|c|}{$5 \%$} & \multicolumn{2}{c|}{$10 \%$} & \multicolumn{2}{c|}{$15 \%$} & \multicolumn{2}{c|}{$20 \%$} \\
\hline & gm & Pias.* & gm & Pias. & gm & Pias. & gm & Pias & gm & Pias. \\
\hline $\begin{array}{l}\text { Soft wheat flour } \\
\text { 3 LE/kg }\end{array}$ & 100 & 30 & 95 & 28.5 & 90 & 27 & 85 & 25.5 & 80 & 24 \\
\hline $\begin{array}{l}\text { Inactive dried } \\
\text { yeast10 LE/kg }\end{array}$ & -- & --- & 5 & 5 & 10 & 10 & 15 & 15 & 20 & 20 \\
\hline $\begin{array}{l}\text { Skimmed milk } \\
\text { powder 10 LE/kg }\end{array}$ & -- & -- & 6 & 6 & 6 & 6 & 6 & 6 & 6 & 6 \\
\hline Cinnamon16 LE/kg & -- & --- & 3 & 4.8 & 3 & 4.8 & 3 & 4.8 & 3 & 4.8 \\
\hline $\begin{array}{l}\text { Sugar powder } \\
\text { 5 LE/kg }\end{array}$ & 28 & 14 & 28 & 14 & 28 & 14 & 28 & 14 & 28 & 14 \\
\hline Shortening 9 LE/kg & 20 & 18 & 20 & 18 & 20 & 18 & 20 & 18 & 20 & 18 \\
\hline $\begin{array}{l}\text { Sodium icarbonate } \\
\text { 10 LE/kg }\end{array}$ & 3 & 3 & 3 & 3 & 3 & 3 & 3 & 3 & 3 & 3 \\
\hline Sweet whey liquid & -- & -- & $40 \mathrm{ml}$ & -- & $40 \mathrm{ml}$ & -- & $40 \mathrm{ml}$ & -- & $40 \mathrm{ml}$ & -- \\
\hline Total cost/Piastres & & 65 & & 79.3 & & 82.8 & & 86.3 & & 89.8 \\
\hline
\end{tabular}

*Pias. (Piastres).

\section{REFERENCES}

A.A.C.C. (2002). American Association of Cereal Chemists, Methods 54-21, In Approved Methods of The American Association of Cereal Chemist, The Association, St., Paul, MN; USA.

Abou-Zaid M.A. (1984). Biochemical studies on Foodder yeasts. $\mathrm{pH}$ D.Thesis Faculty of Agriculture, Cairo Univ. Egypt.

Adamiec J., Kaminski W., Markowski A.S., Strumillo C. (1995). Drying of biotechnological products. In: Mujumdar, A.S. (Ed.), Handbook of Industrial Drying. Marcel Dekker, New York, USA, pp. $775-808$.

Ali Zeinab A., El-Shrif S. A and Talaat S.A. (2013). Utilization of lentil meal and turmeric powder in production colored pretzel with high nutrition value.Egypt J.Agric. Res.91 (1):191-204.

Anown. (2013). The George Mateljan Foundation the World's Healthiest Foods \& Spices. († 2001-2013).
Asad E.A.M.(1983).Comparative study on the methods of reducing nucleic acids in yeasts. M.Sc. Thesis. Faculty of Agriculture, Al-Azhar Univeresty, Egypt.

Batifoulier F.,Verny M A., Besson C., Demignê C and Rêmêsy C. (2005). Determination of thiamine and its phosphate esters in rat tissues analyzed as thiochromes on a RPamide C16 column. J. of Chromatograpy B. 816: 67-72.

Bekatorou A., Psarianos C. and Koutinas A. A. (2006). Production of food grade yeasts, Food Tech. Biotech. 44 (3) 407-415.

Dobranski .Z., Korniewicz A., Dolin ska B., Gorecka H., Jamroz D. and Ryszka F. (2003).

The chemical content and feeding value of enriched with Chromium ,Selenium and Zinc yeast Saccharomyces cervisiae. ISAH, Mexico.

Eid Nafissa.M.M.(1977). Some studies on the utilization of yeast in human nutrition. $\mathrm{Ph}$ D. Thesis, Faculty of Agriculture, Cairo University, Egypt. 
El- Bastawesy Amal m.,El- Refai A.A and ElAshaal Eman S. (2013). Nutritional improvement of healthy talbina drink using germinated barley and oat flours. Egyp. J.Agric.Res . 91(1):219-235.

Food and Nutrition Board. (2011). Dietary references intakes, estimated average requirements: Institute of medicine, National Academies.

Gul S. and Safdar M. (2009). Proximate composition and mineral analysis of cinnamon. Pakistan J. of Nutri. 8 (9): 1456-1460.

Hedenskog G. and Morgan H. (1973). Biotech. Bioeng, 15: 129-142.

Ibrahim I. (2004). Awareness of Teachers of the Relationship between Students' Performance and Nutrition Status: Egypt's Experience. School Children in the Developing World: Health, Nutrition and School Performance, A two-day international workshop under the Global Impact Research Initiative By Richard Gunde.2004.

James C.S. (1995). Analytical chemistry of foods. Blackie Academic \& professional, london,p.135.
LINDS (2007). The impact of malnutrition on children's physical and mental development. $\quad$ WWW.Kidscoplate pledge.org.

Lui J., Raine A.D., Venables P.H. and Mednick S.A. (2004). Malnutrition at age 3 years and externalizing behavior problems at ages 8,11 , and 17 years. Am. J. Psych. 161:2005-2013.

McClave J. and Benson G. (1991). Statistics for business and economics. Dellen Publishing, Fifth Edition. San Francisco, USA.

Pozo-Bayón M. Á., Andújar-Ortiz I. and Moreno-Arribas M.V. (2009). Scientific evidences beyond the application of inactive dry yeast preparations in wine making Food Res. Int. 42 : 754-761.

Prosky L., Asp N., Furda I., Devries J.W., Schweizer T.F. and Hardland B.F. (1984). Determination of total dietary fiber in Foods, food products and total diets, inter laboratory study. J. AOAC, 67:10441052.

Saba N. H. (2005). Culinary Science and Art Book. $9^{\text {th }}$ Edition, Dar Al Maaref . (bup.) Cairo, Egypt. ISBN 977-02-6788-0.

\footnotetext{
رفع القيمة الغذائية للبسكويت بإضافة مصادر طبيعية منخفضة التكاليف عالية البروتين والعناصر المعدنية
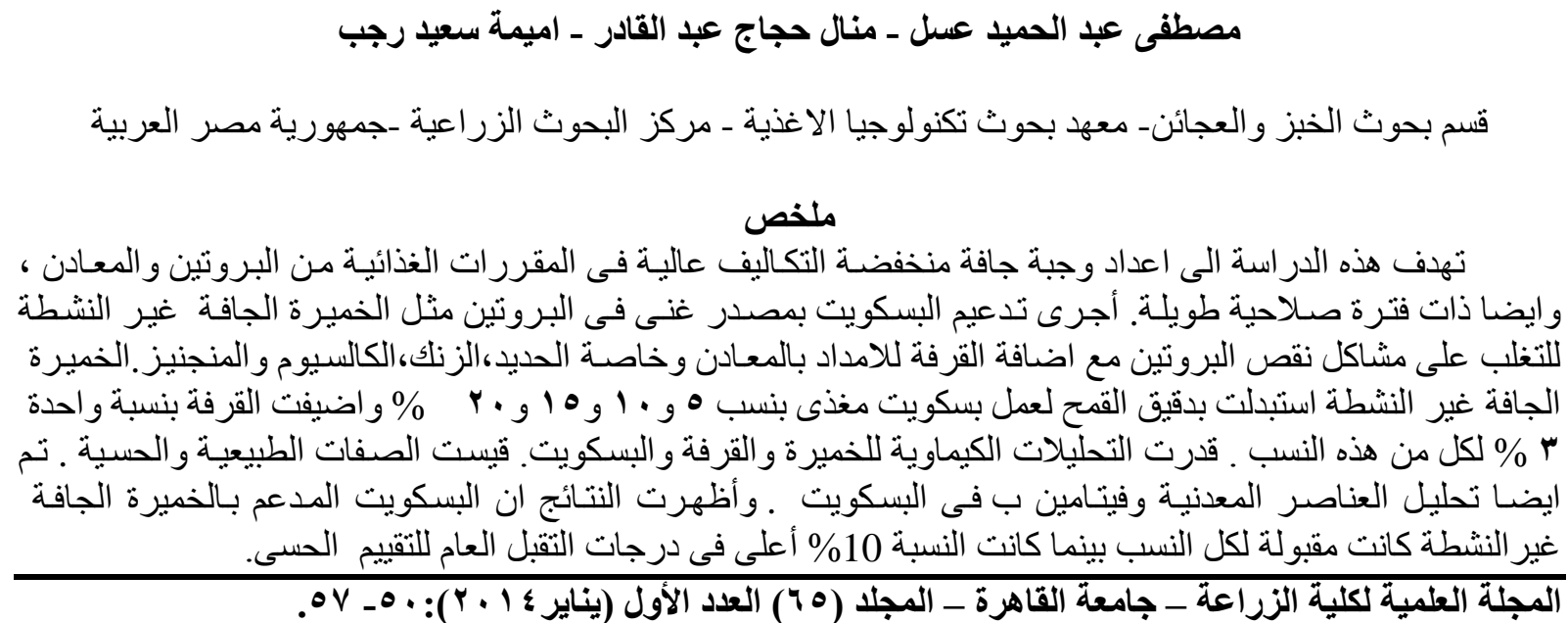